\title{
A Study on Relationship between Dialect and Modern French
}

\author{
Ying $\mathrm{Xu}^{1, \mathrm{a}}$ \\ ${ }^{1}$ Foreign Language Department, School Of Humanities, Tianjin University Of Finance and \\ Economics, China \\ acxy031058@126.com
}

\begin{abstract}
Keywords: Dialect; French; French Teaching; Language.
\end{abstract}
\begin{abstract}
The relationship between dialect and French language is inseparable. They went through a long period of development, both of them can influence each other and rely on each other. In this paper we will compare and analyze the influence of dialect on the formation of modern French from the perspective of linguistics in order to improve the French teaching quality.
\end{abstract}

\section{Introduction}

French, one of the Romain Languages, has many users around the world. It was, in the 19th century, spoken widely than other languages in the world, nowadays, French is considered as the mother language by more than 87000000 persons in the world. One of the five official languages of the United Nations, "logical and highly constitutive, like the songs," all of these findings for French shows us that it is becoming more and more indispensable in our life. With a deep appreciation for French, there are not many people who know that the development of this language has experienced a period of ups and downs, that is the 19th century. In the 19th century, although French was developing rapidly, it had some limitations that we can feel until now. According to the article, «l'orthographe devient de l'Etat en 1832» and «la langue doit être une comme la République» ( «Spelling belongs to the state in 1832» and «the language must be one as the Republic»), the unification of the French language has not only the advantages but also the disadvantages. On the one hand, it speeds up the spread of the French language education which encourages more and more children to learn French, on the other hand, the official language is very difficult to be a recitation of a piece of written language that goes into the ear. That is to say, there is a big gap between the official language and the written language.

In addition, it was believed that dialect had a negative effect on the development of the "reason" in the 19th century. This is the second defect of French. Up to now, a lot of people don't know or will not accept the word "dialect". In linguistics the term "dialect" is not often used by linguists who prefer to use the more specific names. The term "dialect" is assigned a negative meaning for centuries. It is changed, corrupted compared with the noble French. The history, however, cannot ignore these varieties of the French language. The relationship between French and dialect is very close. We feel that dialect, an inseparable part of the language, revealed gradually the richness of the oral language that we talked about for a long time without the recognition. So we're going to do a little analysis on the dialect and its very close relationship with the French language.

\section{The global status of the French language and French teaching in the 19th century.}

The French language has a long history. As one of the official languages of the united nations, French is spoken in 40 countries around the world. When we speak French, we cannot but be attracted by its elegance. It is true that the Europeen aristocrats considered French as the most popular language in that epoch. They spoke French fluently at the banquets to show their noble status and their special way. Up to now, the French language is seen as one of the most beautiful languages in the world. French, the language of the French nation, belongs to the Romance language family. A total of more than 200 million, that is $3 \%$ of the world's population speak French. The most remarkable characters of French are its exquisite pronunciation, its accuracy, and its logic. From the perspective of Linguistics, French is well suited to be analyzed, because it combines the rigour of 
Latin and the sensitivity of Greek which constitute the special style of French. Many well-known writers and linguists have provided the descriptions to the features of French. These descriptions can help us to know the characters of French and give us a very deep impression, although not all of them are accurate and complete. From 18th to 19th century, the French culture and art were very famous in Europe, Antoine Rivarol, a French writer, predicted that the French language, thanks to its perfect communicative and reasonable expression, is not only the language of the French nation, it will be the common language of the world. The language which is not clear, is not French. Here, Antoine Rivarol shows not only the accuracy of the translation, but also the character of the language, that is the syntax is consistent with the logic of the language in the mind of man. In the 19th century, Walter von Wartburg, a swiss writer, also pointed out the characters of French, such as elegance, flexibility, accuracy, etc. According to him, all these characters decide that French will be the most flexible language around the world.

French has a high status in the world today, this is because, on the one hand, its own language characters make it a bright language, on the other hand, the French teaching fosters its generalization. For centuries, the French teaching has grown progressively, unfortunately, however, this process had not always the favorable wind all the way. At the beginning of the 19th century, a lot of people defended the classical French. The defenders not only supported the reforms, but also adopted an attitude against the progress of French. Their attitude constituted, however, the main idea of the French teaching in secondary schools. The development of the French language experienced difficulties. At that time, the eminent persons indicated, compared with Latin in the role of an archetype, that the French have five shortcomings that seemed ridiculous for us today:

There are no variations in the French language;

The conjugaisons of French is very incomplete and defective;

The construction of sentences is overloaded with auxiliary, particles, articles and pronouns;

There are not enough combined words and compounds in French;

The versification of French is mainly characterized by the rhyme.

All the defects of French proposed by the eminent persons in the 19th century make us laugh today, because they constitute the most attractive part in the French language, and become the obvious characters of French, such as precision, accuracy, elegance etc.

Although people have prejudice to the French language, the predominance of the French pronunciation make French a model compared with English that seems to hit the principles of human pronunciation. We can use, with regard to the pronunciation of French, four words in order to describe it: soft, mellow, clear and melodious. When we speak French, we often have the impression that the French talk fast and clear. According to the statistics, the French articulate, on average, more than 250 syllables per minute. They speak the most quickly in the world. Why are they speak faster and more elegant than the people in other countries? And why do we have such high appreciation to the French pronunciation? There are two main reasons. On the one hand, there are more vowels in French than the other languages, such as Chinese, Japanese, etc. On the other hand, when we're speaking, the mouth is in a flat shape, that is in favour of the pronunciation. These two reasons are so favourable to the pronunciation of French and give it, however, a very important position in the teaching of the 19th century when French, itself, was often criticized.

In addition, there are two major developments in the teaching of French in secondary schools. One is that a great deal of the literary works appeared in the middle school textbooks. There are many models of composition, including the narrations, pictures, descriptions, definitions and the speech, the other is that the teachers began to explain the text at the end of the 19th century. The original way of teaching helped the students to better understand the text and to learn more effectively the mode of expression of the authors of the texts. In addition, one of the most remarkable features of the French teaching in 19th century is the rapid development of elementary education. The teachers gave more attention to the spelling of the children and explained in the teaching more thoroughly that the former teacher is not up to do that. 
In the above, we have presented the situation of the French teaching in primary and secondary schools. There is, at the same time, the advantages and shortcomings of the French teaching all of which are the elements that promote the development of the modern French. This process is necessary to the perfection of French. Owing to it, the French language plays a key role in the world and becomes a language that attract more and more foreigners.

\section{The research of the dialect compared with French}

The history of the French language is not the history of the spoken language. That is to say, the spoken language is often overlooked in practice or in the records of the French language. But in the 19th century, we had a very absorband study about the usage of the specific languages that is different from the term proposed in the school. In fact, there are many regional languages, four romance languages (Catalan, Occitan, French in Provence, the Tuscan dialect) and three non-Roman languages (Basque, Breton, and Germanic). The wealth of linguistic in France is always forgotten because of the great prestige of the "French" and the centralization of the country.

Compared with the French language, prestigious national and legitimate, the term "patois" is felt as a derogatory language. it was treated as a "damaged" French, "twisted", "bad", even un « argot » is spoken by the peasants or someone who is rude. The etymology of the word "patois" can be traced back to the middle ages. It would be, reinforced by research, a derivative of the old French " patoier". That is to say, "shake hands, moving to make himself understood". There isn't a verb in a large part of the vocabulary of the dialect, such as singing of the birds, etc. In the 19th century the term patois was common, but derogatory . That's why Ronsard created the term "dialect". In the 18th century, people condemned definitely dialect, at the same time, they looked for a legitimate usage for the language. The reason is very simple, the nation was unified, its language must be national and legal. In this way, the patois is abandoned and can't break up of the adjective "changeful", " rough " or "no rules". The opinion against the dialect in the 18th century was asked by the investigations carried out by the father Grégoire and Coquebert de Montbret, the chief of the statistical office of Interior Ministry in the Napoleon Era. According to the investigation, the people who lived in different dialectal areas in l'Ile-de-France didn't admit that they speaked patois and it was always the people in the other dialectal areas who speaked with an accent. This idea has been around for a long time, up to now, some people who live in l'Ile-de-France believe that there is no accent in their spoken language.

\section{The evolution of the dialect and the relationship with the French language from the point of view of geolinguistics.}

At the end of the 14th century, the romanistes divided the oil language area according to the standard pronuncia. Most of these languages have a name, but this is not the romanistes who created them. All these names were given by their users, for example, the Percheron, Tourangeau, Orléanais, Berrichon etc. In contrast, the situation in l'Ile-de-France is a little different. The languages have not names, this is because the dialect spoken around Paris was taken as bad French. So the differences between the dialect are not well recorded, although there are really large differences between them under l'Ancien Régime and even today. On the map of the investigations of Grégoire and Coquebert de Montbret, these areas are shown in white.

In the history of the dialect, there are two major investigations related to the characteristics of the oral language, the technology vocabulary, the specific expressions of dialect. One of them was carried out by father Grégoire, the other is the investigation of Coquebert de Montbret. Father Grégoire, the full name is Henri Jean-Baptiste Grégoire, is one of the leading figures of the French Revolution and the founder of the national museum of arts and crafts. He read, in front of the Convention on the 16 Prairial a report (named Rapport sur la Nécessité et les Moyens d'anéantir les Patois et d'universaliser l'Usage de la Langue française.) Why did he give a so unfavourable report to the dialect ? At the beginning of the revolution, it was felt that French was not the language of the French people. The unity of the language is essential to unite the people. In this way, the dialect prevented the process of 
unification. Therefore, it was necessary to remove them. In this context, Father Grégoire sent 43 questions to the relevant scholars in order to acquire the information on the various aspects of the dialect, for example, the origin of dialect, the classification of vocabulary, the nature of the pronunciation and the works in dialect etc.

The main idea is that there is no dialect in the region and the French language is universal. It is important to note that the pronunciation is different from the other dialects. They believed that the dialect is an old French spoken at the time of Rabelais and Montaigne. What is regrettable was that they didn't show any remarkable resemblances between the farmers in la Brie and in the suburb outside Paris.

In 1806, the baron Charles-Etienne Coquebert de Montbret, the head of the statistical office of the Interior Ministry, conducted a survey about the language situation of the empire. Compared with the survey of Gregory, we can find that it has three characters : (1) There are more peripheral departments participated in the study, but in the white spots on the map, the department has received fewer answers; (2) In according to Charles Coquebert de Montbret, the varieties of French should be studied and should be replaced in the history of the language ; (3) He thought that the dialect was part of the culture, the habits and customs that was seen as the ancient monuments.

The last two items are the most important of these differences. He established the relationship between the French language and the dialect constitute the foundation of the Geographical Linguistics. G.Paris created the term "francien" in 1889, that was the language of the Ile-de-France and constituted the origin of the French language. from this point of view, there wasn't distinct difference between the language and the dialect. The dialect is not a twisted French, however, French is a successful dialect. Sainte-Beuve wrote: the dialect is an ancient language who was unfortunate.

\section{The use of the dialect in literature of the 18th century.}

It is not difficult to find the dialect in the literature of the 18th century. The literature of the 18th century has not only expanded its scope in the field of the description, it seeks to introduce the people from all walks of life and to match a particular language and style. That is to say, the writers in the 18th century began to use in their work the dialect that was seen as a corrupt language for centuries. Balzac gave us a good example. In his book 《Le lys dans la vallée》, Mme de Lenoncourt used the talking habits of the old court. However, the use of language is not easy for the writers who tried to express the characteristics of the characters by the spoken language, because the dialect have their own characteristics. First of all, the dialect is often understood in a radius of a few kilometers. This sometimes resulted in the problems of understanding of the readers who spoke other dialect and of the foreign readers, although the dialect of the characters was able to reflect the characteristics of their languages and the social environment where they came from. In addition, in view of the fact that the dialect was used in the literature in order to describe the characters and their social environment, the literature of the 19th century is marked by the development and diversification of the vocabulary.

\section{Conclusion}

The 19th century is a brilliant era in the history of the French language. The French teaching has been widespread in secondary schools, although we have met some difficulties in this process. The change in teaching methods has stimulated the children's potential in the process of learning French and has promoted the development of French. At the same time, the dialect that was ignored for centuries successfully attracted the attention of the writers in the 19th century. They began to introduce it into their work to describe more precisely the characters and their social environment. The dialect is an inseparable part of the French language and influence our lives all the time. We should pay more attention to it, in this way, the development of the French language will be more comprehensive and more rapid. 


\section{Acknowledgement}

This research was financially supported by the Tianjin Philosophy and Social Science Project of Research and Planning (Grand NO.TJTY15-003).

\section{References}

[1] Galisson(R), 1991, De la langue à la culture par les mots, Paris: Clé international.

[2] Armand Matelart, 1996, La mondialisation de la communication, Presse universitaire de France.

[3] Béatrice Bouvier, 2003, Chinois et Français : quand les habitudes culturelles d'apprentissage s'opposent, Etudes de linguistique appliquée, Numéro 132, Didier Erudition.

[4] Jean-Marc Colletta, 2005, Communication non verbal et parole multimodale:quelles implications didactiques, Clé International.

[5] John.J.Gumperz, 1998, Sociolinguistique interactionnelle, Harmattan. 